\title{
Black Bodies on South African Beaches: Lus en smaak jou lekkerding ${ }^{1}$
}

\section{Rozena Maart \\ ORCID iD: https://orcid.org/0000-0002-3829-1523}

\section{Abstract}

This article examines the outbursts of Penny Sparrow and Vanessa Hartley on social media, both of whom directed theirs at the Black beachgoers of South Africa in late December 2015 and the early days of January 2016. The article recognises the events of \#KingGeorgeMustFall at the University of KwaZuluNatal and later \#RhodesMustFall, which began in March 2015 as one of the

${ }^{1}$ Lus en smaak, jou lekkerding, as per the subtitle of this paper, contain four distinct words that are not of the English language, and have their particular meaning outside of its culture, expression and discourse of desire; they are expressions in Kaaps, a vernacular that developed during the period of the enslavement of people forcibly brought to the Cape by the Dutch from Java and Malaysia in the 1600s and the Xhosa from the Eastern Cape, and is still spoken today by people from this previously enslaved community. Both lus and smaak, as expressions of desire are unpacked in the second part of this paper. For the present, it is important to note since the article is written in English - one of the two colonial languages in South Africa - that lus when translated in English as wish especially with regards to one's appetite for food (wishing for a piece of freshly fried snoek...) and yet not limited to it can never find full expression in the English language. Likewise, smaak is used to refer to the desire for another ... of the sexual and libidinal kind. Jou, addresses the person, as in 'you' and 'your' as one would direct oneself to another in the English language. Lekkerding does not exist in the old Dutch dictionary and was retained by the previously enslaved community to refer to a person who one is sexually attracted to and who one finds sexually arousing. One could translate it in more colloquial terms in English, if one must, as 'you sexything'. 
backdrops of this discussion on physical space as politicised space and assert here the crucial components of flora and fauna such as the sea, sand, and the beach within a larger discussion on decolonisation. Discussions on decolonisation in South Africa have to include a critique of beaches as sites of enjoyment, which considering its colonial and apartheid history has since South Africa's transition towards a democracy ${ }^{2}$ brought about an annual outpour of racist outbursts on social media, more particularly in the past decade, that foregrounded its racism by attacking Black bodies. In unpacking the content of Sparrow's first posting, mainly, and her subsequent published apologies during interviews with journalists, the article moves towards a discussion of the Hegelian master and slave dialectic with a focus on desire, enjoyment and pleasure. It follows on with Lacanian jouissance, which is merged through the use of a South African language of desire drawn from the

${ }^{2}$ I take exception to the notion that one person, one vote, which took place on the $27^{\text {th }}$ of April 1994, after 342 years of settler colonialism, constitutes a democracy. Demos - the people, and kratia - power, rule, as such, the rule of the people, did not happen, and is still not in operation in South Africa. Likewise, I have similarly spoken against the concept of 'freedom's children', that is, the common expression that April 27 ${ }^{\text {th }}, 1994$ heralded in the era of freedom and children born then, and shortly after, were born into freedom. Various scholars refer to the period immediately after April $27^{\text {th }}, 1994$ as the period of transition; others assert that one vote offers democracy its definition. Not only does South Africa's Constitution not hold its usurpers and colonisers accountable for four centuries of plundering and unlawful extraction of minerals to accumulate wealth, but the land also has not been given back to the Indigenous people and those colonised in the process through different forms of enslavement. Currently, the material conditions under which the coloniser and the colonised live remain unequal, with the former constituting ten percent of the population and still maintaining eighty-nine percent of the country's wealth. Equality under the law suggests personhood is granted and equality extended across the designated region because those to whom he, she or they have been made equal to, in other words, the backdrop of the White experience against which equality has been granted, extended and offered, suggests equality of living conditions. This is the furthest from the truth in South Africa. Settlers draw from their Whiteness as property, forging a disproportionate setting for the colonised to live as equal under the law. 
Kaaps vernacular (see footnote 1), with a Fanonian, Derridean and Bikoesque lens in addressing Black bodies on South African beaches as subjects who are agents and carriers of pleasure, surplus pleasure and orgasmic pleasure.

Keywords: Black bodies, beaches, simianisation, desire, envy, enjoyment, pleasure, jouissance, lus, smaak

\author{
Penny Sparrow \\ These monkeys that are allowed to be \\ released on New years Eve And new years \\ day on to public beaches towns etc \\ obviously have no education what so ever \\ so to allow them loose is inviting huge dirt \\ and troubles and discomfort to others. I' $m$ \\ sorry to say I was amongst the revellers \\ and all I saw were black on black skins what \\ a shame. I do know some wonderful \\ thoughtful black people. This lot of \\ monkeys just don't want to even try. But \\ think they can voice opinions about statute \\ and get their way dear oh dear , from now I. \\ Shall address the blacks of south Africa as \\ monkeys as I see the cute little wild \\ monkeys do the same pick drop and \\ litter.

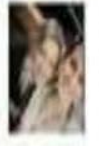

Vanessa Hartley They like stupid animals. We should tie them to a rope. To many Africans flocking to Hout Bay. Draw up a petition. Soon there will be nothing left of Hout Bay.

\section{Introduction}

This article forms part of a collection of essays from my forthcoming book, Black Consciousness and the Politics of the Flesh, where a more elaborate account of some of the contents discussed here can be found. It examines the outbursts of Penny Sparrow and Vanessa Hartley, on social media, both of whom directed theirs at the Black beachgoers of South Africa in late December 2015 and the early days of January 2016. Sparrow commented on Black people on the beaches of Durban and Hartley regarding Black people on beaches in the Hout Bay area, a seaside town on the Atlantic seaboard of the larger Cape Town area. Due to the limitations of papers of this kind, Vanessa Hartley's 
social media postings and subsequent action is not offered here for critique but have been drawn into the discussion to show the liberty with which White women have exercised their 'freedom of speech' when it comes to Black bodies. This article recognises the events of \#KingGeorgeMustFall at the University of KwaZulu-Natal (UKZN) and \#RhodesMustFall, which began in December 2014 and March 2015, respectively, as two of the backdrops of this discussion on physical space as politicised space and assert here the crucial components of fauna and flora such as the sea, sand, and the beach within a more extensive discussion on decolonisation.

The University of Cape Town (UCT) student, Maxwele Chumani, took it upon himself to bring human faeces from Khayelitsha, which he threw on the Cecil John Rhodes statue. The statue stood as a reminder of Rhodes' actions as a colonial, displayed with reverence at higher learning institutions and constructed by slave labourers drawn from the Cape, which students did not want to see. Discussions on decolonisation in South Africa have to include a critique of beaches as sites of enjoyment, which considering its colonial and apartheid history has since South Africa's transition towards a democracy brought about an annual outpour of racist outbursts on social media, more particularly in the past decade, which focused on attacking Black bodies. In unpacking the content of Sparrow's first posting and her subsequent published apologies during interviews with journalists, the article moves towards a discussion of the Hegelian master and slave dialectic with a focus on desire, enjoyment and pleasure. It follows on with Lacanian jouissance, which is merged through the use of a South African language of desire drawn from the Kaaps vernacular, with a Fanonian, Bikoesque and Derridean lens in addressing Black bodies on South African beaches that the reader is acquainted with the Kaaps discourse, as utilised herein.

\section{The White Woman Subject Declares her Written Text as Reason}

The deconstruction of the White woman subject who offers her speech as text, as the location of reason, must take place most methodically. What makes Sparrow a White subject is her relationship to the system of White domination as agent, beneficiary and reproducer of White domination: upon being racialised within the family context of her birth and socialisation that set the material conditions of her existence, she enacts, maintains, and reproduces the 
system of White domination through her agency - physical, bodily, fleshed ability to act, intervene, interject, through speech, writing, bodily presence, and convey thoughts and ideas that she enacts. Whilst a grotesque outburst, Sparrow, the author of the first inscription (hereafter referred to as Sparrow 'Post One') and Hartley, the author of the second posting noted above, declare their public writing as a necessity by revealing the anatomy of their thoughts. In this article I focus primarily on Sparrow's posting: it is one of discontent a disgruntled, displeasure - that starts with the depiction of Black people as monkeys then unfolds as a discourse of disgust by situating the presence of '... dirt and trouble and discomfort...' Sparrow's White subject identity, much like Hartley's, is affirmed by the photographic display of an image of herself beside her name as per the protocol of Facebook and privileges her discontent to her White readers; it also acts as an accomplice to her outburst as a performance of reason besides her reasonable White face, which seals the assertion. For one, such reason appears, as it does above, forcefully, piercingly because one can see who exactly the disgruntled White subject is. One cannot by the content of the White subject's text above, riddled with grammatical and syntax errors assume that it is not worthy of the attention of decolonial scholars and as such irrelevant for any form of philosophical inquiry because it does not resemble the inscriptions we have been taught to value as scholarly. I undertake a revelation of Sparrow's careful wording with precision - grammatical errors included - not only because it made the headlines and sparked country-wide debate but due to its content. Sparrow's 'Post One', displayed above, went viral and received more than 200000 citations within 24 hours after it was posted.

In March 2020 I presented some of the work noted in this article at the African Phenomenology conference held in Chintsa, some 35 kilometres outside of East London on the east coast of South Africa. One of two of the White women who were asked to read and comment on my article (who incidentally holds a senior position in a philosophy department at a former Whites-only university in South Africa), noted that it was difficult for her to read it, and that she was bothered that I had cast all White women as 'Penny Sparrows'. In questioning the organisers of the conference about why they sent my article to the abovementioned White woman, I was told of her benevolence and how, of late, she has started to do work on race. The alleged work for which they praised her, which marked her as a worthwhile reader of the kind of work that I produce, I read as textual work - the kind where the white woman scholar applies herself to the text and wilfully removes herself from any form of 
responsibility for racism, especially under the watchful eye of critical race scholars. White women did not organise mass protests to take a stand against Penny Sparrow's racism. Instead, Sparrow was ridiculed for her lower-middle class sensibility and mocked for not being sophisticated enough to hide her racism.

Sparrow's 'Post One' has to be understood word for word - as it offers insight into the anatomy of her thought process, her consciousness of self and consciousness of the other - Black people - as is revealed in her vocabulary of choice. The approach I employ here as a philosopher who merges Black Consciousness, Derridean deconstruction and psychoanalysis, is to address the relationship between text and meaning, between consciousness and politics, between the scene of the crime - the sea, as both the site of usurpation and uninvited docking of carrier ships performing their enslavement and transport of the very Black bodies now reviled - and the shores, the beach, the space between the sea and the land, between the waves that allow frolicking permitted by the law, and the sand that allows a site for gathering, a space to enact leisure with friends and family, where the labourer, the enslaved, the colonised, of interlocking identities, are transformed from worker to sunbather. Biko's Black Consciousness focused on the mind, as did his predecessors, Sobukwe and Lembede. 'Man is body, mind and spirit with needs, desires, aspirations in all three elements of his nature' (Lembede 2015: 129). The mind is part of the body; the mind is the seat of consciousness, and the body the stage upon which consciousness exerts itself.

The attempt undertaken here is to reveal the salient features of Sparrow's text; a text that sought to inflict cruelty, tried but failed to curb the enjoyment of Black people on South African beaches, which up until 1989 only the coloniser had been privileged to enjoy. I now revisit the opening sentence of Penny Sparrow's 'Post One'.

\section{These...}

A declaration, a dissociation from the self. The depiction of the 'the other' ... a thing, a nameless item that does not deserve a name. These - the word - is usually accompanied by 'them' and 'they'... the words depicting distance from the speaker. The subject who speaks, distances, scoffs, calls people these. We see the full sentence, the criminal sentence, the line of punishment, as the speaker utters these at the start of her sentence... at the start of the writing from 
left to right that says, not me, not I, and scoffs, scolds, laments. We take out, extract, and examine it before we place it alongside the words that come after it. The word these when declared against other subjects, subjects whose identity, we learn, will be uttered shortly after. The word these is the start of her scolding words, scathing words, her words against the law, against the law of expected human civility towards the previously enslaved, the previously oppressed... her words are spoken against the burial of apartheid. These - the subject, term, phrase, expression that says 'you are not me'... I keep you away from me.

\section{These monkeys...}

To repeat the first word - these - and place it with its accompaniment monkeys. This is the subject of her text, a subject that is written as a concern. These monkeys ... Sparrow begins. Sparrow addresses her readers and informs them of the subject of her discontent. We know that she is not addressing the vervet monkey species of Durban. There is a photo of Sparrow beside her text. The pairing puts any reader of the text who is Black in the picture immediately. You are now in the frame. You move from reader to being read. You are being looked at as a monkey. There is a frame; you are within it and Sparrow as your uninvited gazer has now invited her ilk into a viewing. If you're a Black person, you are these monkeys. You are the monkey - the object of her gaze; the gaze of this White woman and her White Facebook friends who she draws upon as viewers and listeners. You are being looked at. As you read, Sparrow's words draw the picture. You are looking at Black people; you are looking at an image of yourself. You cringe in anticipation of what is to come. As a Black person reading, you know that Sparrow is referring to you, to Black people whether they look like you or not. You are in the know because experience determined this kind of knowledge; the experience of being called a monkey and being witness to family members - your uncle, your grandfather, your sister, your friends - being called monkeys. You are not only in the know because you have information of this act of cruelty but this kind of taunting remark, accusation, clear and outright no-need-for-a-dictionary-interpretation-of-racism has come knocking at your door and hit you in the stomach before, twisted your colon, spat in your face, reduced you to a breadcrumb, kept you from the dinner table, kept you in anticipation of what was to follow... The bile in your stomach became more acid, you could not control the anatomical reaction of your body, much as your thoughts and your command of the English language begged you 
to. Reviled, angered, you spoke out in defence of the cruelty, but your trips to the toilet could not be contained. You are familiar with it because it forced itself onto you before, uninvited, it now thrusts itself upon you again - just like that. The last time, the stamp of racism, yesterday, the day before, last week, has not faded. Your memories of racism are retrieved; they return, in an instant. You remember. You recall. You retrieve again from the trace of the last memory. The images flash upon your mental screen. You are, in that very moment of the reading of the phrase ... these monkeys, the animal, the vile animal, the unintelligent non-human animal. You know that Sparrow is not writing to Black people; she is writing about Black people with the understanding, however peculiar, that she is writing to White people, who are not these monkeys. There are only two sides to the phrase these monkeys, and if you are Black, you are on the side where scrutiny is about to fall. And as such, you continue with the reading.

\section{that are allowed ...}

To be allowed means that someone had to give permission for you to gain entrance, be permitted to a place; someone who had ownership of your whereabouts, of your existence. To exist as a person who needs to be allowed means that you exist under erasure, having been cautioned, you live under kanala $^{3}$ - a word from the Kaaps ${ }^{4}$ diction that asks [with the word] please, and

3 The word kanala is used among the Cape Malay and Cape Coloured population and resembles the English expression of 'do me a favour'. Most people at the Cape credit the word as one that is Cape Muslim. The word kanala has Indonesian origins, where it was formerly expressed as Karna Allah. Before District Six got its formal name in the middle of the 1860s, it was affectionately called kanala town due to the term kanala being in regular use among the enslaved population. It is as such a word considered to be part of the Kaaps vernacular.

${ }^{4}$ Kaaps is a language that developed quite distinctly from Dutch, although most of the language can be traced to a 17th century Dutch injected with various diction brought into the language by the previously enslaved, spoken among the enslaved from Java and Malaysia primarily then the KhoiSan, enslaved people from Madagascar and coastal African countries. It is still 
does so under protest. Sparrow situates the prohibition - the apartheid laws of ownership, who is allowed and who is not, who will be allowed, and who will do the allowing. Allowed speaks of granting permission to movement, of being permitted to go somewhere, of transporting your forbidden body to a place because someone other than you had access to it, to land, to space and had the ability to situate Black presence within it. The allower was your master; the allower reminds you and other masters... masters who allowed you. The notion of allowed is brought into the opening sentence of Sparrow's complaint. It is a reminder of what was before - what was a state of disallowance, of prohibition, of impossibility and restriction of movement being a law created first under slavery at the Cape in 1709 where the enslaved carried passes, then close to the end of the 1700s the Khoisan were forced to carry permission documents. Thereafter, over the decades, into the 1900s, old laws were amended, and new laws were designed, into the formal period of apartheid to keep Black people out, away from, barred; the objective: to prohibit, to throttle the possibility of movement. The only allowance for the enslaved and Indigenous people of South Africa was that of servitude 5 .

By 1948, when the National Party came into power, three strategic acts of prohibition paved the way for apartheid: the Population Registration Act of 1950 Act, the Prohibition of Mixed Marriages Act of 1949 and the Group Areas Act of $1950^{6}$. When Black women were allowed to enter the city-centre, it was to work as domestic workers - paid subordinates. The allower, was the master, and the master mastered the law. Just two months after assuming the presidency, F.W. de Klerk allowed Black people to swim at previously classified White beaches. The desegregation of beaches was part of his gesture of goodwill, and on the $16^{\text {th }}$ November 1989, the apartheid negotiator declared that beaches were no longer to be segregated. The allower who allowed... this

spoken at the Cape today, and around the country by those who were influenced by it, and now live in other provinces.

http://capeafrikaans.blogspot.com/p/what-is-Kaaps.html

${ }^{5}$ I am here alluding to the history of pass laws in South Africa

https://www.sahistory.org.za/article/pass-laws-south-africa-1800-1994

${ }^{6}$ I am here speaking to the three main laws of apartheid.

https://www.bbc.co.uk/worldservice/africa/features/storyofafrica/12chapter7. $\underline{\text { shtml }}$ 
allower Sparrow indirectly speaks of dates back much further than F.W. De Klerk's 'noble' gesture in 1989.

\section{allowed to be released ...}

And I shall backtrack to the start of her sentence. 'These monkeys that are allowed to be released..'. Sparrow places the responsibility of Black people's presence on something and someone that did both the allowing and the release. The allowing, in turn, led to the release. Two acts were brought into play; two acts of illegality were brought into action: one which allowed; the latter, led to the second act of illegality - the release. De Klerk allowed for Mandela to be released; de Klerk did the allowing, only on the condition that Mandela promised not to fight his master. Mandela had to negotiate his freedom from his baas, his master . . . the master who owned him. The middleman, between God and 'the Natives', Bishop Desmond Tutu, was called upon to ensure that the previously enslaved 'behave' and agree to the baas' terms established during negotiations so that he allows the release of Mandela into the hands of God, into the hands of forgiveness - with no resistance. Allowed - is as such, an act, an event, which was righted from a wrong but as Sparrow determines, was wrong. And since it was wrong there must have been a reason for it to be wrong. It was wrong because Sparrow suggests that the allower (De Klerk and his political party) have been proven wrong. There is the allowed (the act) and there is the released (the objects); the latter as though the allowed were in captivity, secluded, isolated, damned. Damned - there it is again. The Fanonian damned, Césaire the poet, Fanon's mentor used the term on several occasions - damnés. There have been many translations of the French word, but I shall venture to assert condemnation, a sentencing, a lifetime condemnation, the ultimate punishment for being Black.

For Sparrow - allowed is an act, an event, an allowance, a gesture of goodwill only because the decision-maker of the released acted on behalf of the captive and released them! It is both a gesture and a decision that only an allower can make... allowed to be released... let it ring in your ear... allowed to be released ... to be permitted, to have your permitter - the one who rewrites the law, removes the shackles around your body, and issues you the permit prescribing your movement - allow you to escape from the prison of your home, your ravished land he sentenced you to ... you are permitted to leave your confinement. You may leave. Do not be mistaken - you have not been 
set free - you have only been released. There is no freedom, there is only the memory of enslavement, until...

\section{on new years eve and new years day ...}

Written with grammatical errors, with little care for the rules of her colonising language, Sparrow notes the days that mark the event. Here the days of the year, the precise dates, their significance, is key to the disgruntled Sparrow. Sparrow indicates the significance of the holiday dates - new year's eve (sic) and new year's day - considered the most significant of the entire year for holidaymakers and vacationers. These are days marked by the knowledge of holiday, a celebration, an opportunity for leisure. Sparrow could easily have written or abbreviated the dates as December 31st or January 1st. For it is the significance of the days most noted for holiday celebration - masters and the enslaved, masters and the previously enslaved - that she situates as reason one, the first reason for her discontent: the days marked as leisure that she is disgruntled about because those two days were taken away from her; she has to celebrate in her home. The paid subordinates, the factory workers, the mineworkers, the supermarket workers, all of the exploited and downtrodden who do not work on this day have been allowed to be released onto the beach.

Sparrow did not stop with her first written post; she did several interviews with local newspapers thereafter, each time offering justifications for the content of her first post (Sparrow 'Post One'). On each occasion, she supplemented them with various forms of reasoning, some of which included backtracking, and only seconds later as though unrelated to her earlier remarks, she reinforced the very act of racism for which she had just sought pardon. In an interview with News24 on January 4th, 2016, Sparrow revealed several sets of details, which allow us to understand the extent of her disapproval of Black bodies on beaches. Following the initial quote, four segments of Sparrow's response are cited here as a means to unravel both the journalists' critiques of Sparrow's 'Post One', and to unpack Sparrow's responses to their questions .

Reporting on the matter, the News 24 journalist introduced the matter as follows:

Embattled KwaZulu-Natal realtor Penny Sparrow, at the centre of a race-row that has gripped the country, has said that she was merely 'stating the facts'. She had taken to Facebook and described black 
beachgoers as 'monkeys', in an apparent reaction to litter left behind after New Year's celebrations. There has been a mass reaction to her statement across social media platforms, as well as from political quarters. Speaking to News 24 , she revealed what had driven her to compare black revellers to monkeys.

Every year it is the same story; it's their [black people's] day and we don't go in [to] the beach, we don't interfere, we let it be. We all know it and there is nothing wrong. We stay out of the way and stay at home', she said. 'It is their day'.

https://www.news24.com/news24/southafrica/news/its-just-the-factspenny-sparrow-breaks-her-silence-20160104

i. Sparrow, as though in reverence to the colonial frame of the 1800s, reminds us that the enslaved have been given the day off from their masters. In the Cape, it is coon carnival time - treated by many ignorant White liberal scholars today as contentious due to interpretations of the history of Blackface that was popular in the United States of America (USA); it is easier for modernday White liberals in South Africa to be acquainted with the history of Blackface in the USA than the history of slavery at the Cape. In the Cape, the coon carnival started as a celebration to commemorate the end of slavery. In the Cape, we have Nuwe Jaar (New Year), and we have Tweede Nuwe Jaar (Second New Year, the day after New Year), since the middle of the 1900s and has been in operation and with more than 13000 people in attendance at this celebration. Under colonialism, slaves got the day off on the 2nd of January and were allowed to celebrate in a manner of their choosing. Slavery was officially abolished in the Cape on 1st December 1834 but the first carnival was only hosted in 1887 . The official abolition of slavery at the Cape did not prevent White colonials from drawing the enslaved into building the Whitesonly UCT, where recently the remains of bodies that date back to the middle of 1800 s were found. Ancestral remains as evidence have a way of slapping the face of the colonisers just when they think they have rid themselves of their history as enslavers... their Whites-only university is turned into a crime scene, yet again.

Sparrow's condescending historical reminder is her means of referencing the past where Black people form part of the previously enslaved, 
previously oppressed, previously colonised. 'It is their day', speaks to the knowledge of Black people's timely exercise of pleasure - that it is reserved, planned, calendarised, contained, limited, timed, like so many aspects of Dutch coloniality including the surnames (also known as last names), of so many of us at the Cape forced upon us to note our month of enslavement, mine included, which are both September and Maart. Even the word carnival, from the Latin expression carne levare, the removal of the meat, later adapted to the Christian guilt-laden expression of 'indulgence of the flesh', the 'pleasure of the flesh', before the month of Lent. As such, carnivals were generally held in February or March, before Lent, as in Brazil, and Mardi gras - in French already utilised in English as 'Fat Tuesday', the Tuesday before Lent. It is on these dates where indulgence of food and flesh are allowed, as celebrated in the French quarters around the globe, particularly in New Orleans but also in Cape Town, where it is usually held in February. From 6th April 1952, to commemorate 300 years of settler colonialism in honour of Jan Van Riebeeck, the whole country was given the day off to celebrate the man who robbed us of our land and plotted our demise. We were expected to celebrate our colonisation, enjoy it with a braai, enjoy ourselves with alcohol, the remuneration offered to farmworkers' under the tot system ${ }^{7}$ - our pleasure had to be linked to our enslavement and our colonisation. Thereafter, from 1980 Van Riebeeck's day was called 'Founder's Day' until 1994.

In the second segment of her response, Sparrow notes the following:

ii. 'I am sorry that it has taken such a viral turn, but it was just a statement of how it was. I made the mistake of comparing them [black people] with monkeys. Monkeys are cute and they're naughty, but they [black people] don't see it that way, but I do because I love animals ... I wasn't being nasty or rude or horrible, but it's just that they [black people] make a mess. It is just how they are'.

${ }^{7}$ The tot system, also known as 'die dop stelsel', referring to how alcohol is consumed, with a glass known as a tot, legally allowed wine farmers to pay their workers in alcohol, with little to no money, certainly not a living wage. Although the tot system was outlawed in 1960, the practice was carried out for more than 30 years into the 1990s, with warning letters to farm owners that the practice had become illegal. 
https://www.news24.com/news24/southafrica/news/its-just-the-facts-pennysparrow-breaks-her-silence-20160104

Sparrow justifies her comparison and partakes in the history of simianisation of Black people - From King Kong to the tokoloshe and the boogeyman (Maart 2014). Simianisation infantilises. It also exaggerates: the Black man is usually the target, both the creature of depravity where he wants the White woman, and where he cannot control his animal lust. Sparrow's deep-rooted racism by far outweighs any possibility for reason. Sparrow does not read the newspapers, she has not read the responses by members of political parties; she speaks as though apartheid is alive and well, and her frame of reference in offering both an apology and a reason for the ill-fated text, all points to the Trump-style racism that got the latter elected in 2016 as president of the largest democracy in the world. The belief was, and remains, that Sparrow's ignorance, much like Trump's, is in fact, the voice of the [White] people. There are two particular sympathetic approaches: a. the voice of the joker, and b. the voice of the underdog. I proceed here with the former before addressing the latter.

A. The voice of the joker. Sparrow's 'Post One' was posted on Facebook, where a photo showing a younger, slightly glamorous Sparrow stood boldly beside her outburst. Newspaper articles one week later constructed Sparrow as the 'old White lady' with her 'funny wig' and a 'funny hat' both of which were noted to convey her age and to convey to readers that she was in hiding. We had walked straight into Freud's Jokes and the Relation to the Unconscious ([1905] 1966 led by Sparrow's actions, and the actions of Trump. A joker's appearance - hair, facial features, and general appearance - speaks to the seriousness of their actions, and here both Trump and Sparrow, with the focus on their hair, seal the deal. Sparrow's appearance was meant to force us into pity or mockery rather than tackle the content and magnitude of her grammatological dissemination and the harm it had done across the country. Two years after Penny Sparrow's 'Post One', which had the country talking for months on end even after she was found guilty of hate speech by the Equality Court and instructed to pay R150 000 to the Adelaide and Oliver Tambo foundation, and later charged with crimen injuria (under South African common law 
defined as unlawfully impairing the dignity or privacy of another person), Adam Catzavelos, while on holiday in Greece, gave his family and friends a weather and surrounding report: 'Let me give you a weather forecast here. Blue skies, beautiful day, amazing sea, and not one $\mathrm{k} * * * * *$ in sight, (it's) $\mathrm{f} * * * * * *$ heaven on earth, you cannot beat this', he said in the video. In a nutshell, Catzavelos took delight in being at a beach without Black South Africans but used the historically loaded word to refer to Black South Africans. In 2016, like Catzavelos in 2019, Sparrow had not entered the gates of democracy, even after a 'one person, one vote' was put in place and the country's constitution hailed as one of the most liberated in the world.

https://www.iol.co.za/the-star/news/soweto-pensioners-lend-supportto-racist-adam-catzavelos-in-court-42646472

B. The voice of the underdog. The underdogs in the context of South Africa at the time of Mandela's release were the Afrikaners, who consider themselves the underprivileged and have drawn a similarity with the Québécois in Canada, thus asserting the need for land allocation within which their culture, language and history can survive. The Québécois assert their 'right' against the English coloniser, who they see as overlooking their rights for self-determination in the province of Québéc. This is still the voice of 'the poor White' in South Africa, and the voice of 'middle America' in the USA (where the term working class is considered an insult), that scholars are chastised for criticising. There is an assumption that the underdog, that is, the unintelligent, ignorant, uneducated, uncouth Afrikaner Weerstand Beweging [AWB] supporter, the Ku Klux Klan supporter in the USA, who often suggest that they are poor because Black people are taking 'their jobs'; in the South African case, the enjoyment of Black bodies on 'their beaches' drove the underdog to racism.

Sparrow continues:

iii. 'I put an apology up to say I didn't mean it personally. That day on that beach it was all black people, I'm sorry to say it, but it is a fact of life. I said it as I felt it and I know it was wrong to do it on a public thing [Facebook] 
like that. I don't know how it got out and we were all saying it', Sparrow added.

https://www.news24.com/news24/southafrica/news/its-just-the-facts-pennysparrow-breaks-her-silence-20160104

Sparrow apologised for her post being public; She remained oblivious to disseminating words and ideas through social media and the fact that everyone around the country had access to her words, Black people included.

Reason: Sparrow establishes the presence of others.

White reason: reason by racial affiliation to, and membership of, the system of White domination.

Sparrow exclaims: 'we were all saying it'.

Sparrow seeks out her ilk in producing her reasoning.

iv. 'I realise now that they [blacks] obviously hate that. I don't recall putting it like that. I just remember saying that there were so many black people like monkeys dropping things everywhere... making love in the bushes is, you know, fine if that is what they want to do, but the dirt was just terrible', she said.

https://www.timeslive.co.za/news/south-africa/2016-01-04-penny-sparrowbreaks-her-silence-monkeys-are-cute-and-theyre-naughty/

We see here, Sparrow referring to 'making love in the bushes', and the plot thickens. Sparrow offers another component for us to understand the reason(s) for her discontent.

But it is the closing statement below, as part of the lengthy interview that was conducted by The Witness, that puts the full range of her colonial upbringing into the frame, and Sparrow as the one seeking familiarity with Blackness as a means to redeem herself. The latter, a gesture whereby we see many White women these days try to claim kin - suggesting their emergence within Black culture, that they have Black heritage, a Black language, an affinity to Blackness, a Black paid subordinate such as a nanny who was 'like a mother' to them, and they are therefore, not as White as their White privilege suggests.

Sparrow continues: 
v. 'It was an absolute mistake. I didn't mean to hurt anybody or to be racist. In fact, I am very good and kind to black people and help those in need. I was born in East Africa and I grew up with them. My first language was a black language. Swahili. My post wasn't a personal threat against anybody. It was just a comment on the state of the beaches and town' (The Witness 05 January 2016).

And as such, we now learn the following: Sparrow did not mean to be racist. Sparrow is now an East African. Sparrow is now a Swahili speaker. Sparrow wants us to know of her benevolent character - she is the good White settler who is kind to the natives. Sparrow retrieves the domestic, the paid subordinate, takes them out to be revealed. Sparrow now claims Swahili as her language, her first language. Nothing says it clearer: Sparrow's 'first language was a black language'. Sparrow knows Black people more than we know ourselves. When the White woman fails at being White and let out some of the unspoken tenets of racism, reserved for gin and gossip, oftentimes referred to as tea-time and trashing of the natives, that take place in seclusion, at tightlyknit tables in the White suburbs, none of their ilk defend them. Sparrow spoke publicly and betrayed liberal White South Africans because she did not have the political savvy to hide it as well as English-identified Whites. Sparrow, the White woman now digs a place for herself within Blackness. Jacques Derrida's insight into Sparrow's actions says it loud and clear: 'If Being is in effect a process of reappropriation, the "question of Being" of a new type can never be percussed without being measured against the absolutely coextensive question of the proper' (Derrida 1982: xiv).

\section{Unpacking Sparrow's Discontent through Black Conscious- ness, Psychoanalysis and Derridean Deconstruction}

To enjoy, one needs a body ...

Even those who promise eternal bliss

Cannot do so without involving the body:

Glorious or not, it must be there ...

Because for the body, the dimension of jouissance

Is the dimension of its descent into death.

(Lacan Unpublished 1971.) 
As a means of thinking through Sparrow's discontent with:

(i) the Black subject's capacity for enjoyment;

(ii) the enjoyment of Black bodies by Black people;

(iii) the capacity Black people have for enjoyment on previously White beaches - the site of White privilege as White leisure, the very site of exclusion for which legalised White privilege was created in order for White South Africans to perform enjoyment as masterdom over the usurped, enslaved and the colonised - I turn to a psychoanalytic approach that I position within my Black Consciousness lens, both through Fanon and Biko, vis-à-vis Lacan.

The psychoanalysis that I employ traces its fundamental tenets - consciousness, the unconsciousness, consciousness and its relationship to materiality, as such consciousness and politics, language as speech, writing and the imagination, particularly the interpretation of dreams - as key, not limited to but directly related - to Egypt, which much to the chagrin of the empires in Europe and the USA prefer to classify Egyptians as White ${ }^{8}$. Joseph, the dreamer, the second youngest son of Jacob, the son of Canaan who interprets the dreams of Pharaoh and saves Egypt and her people, offers us one of the first psychoanalytic moments in my conceptualisation of psychoanalysis. As such, it forms part of what I consider the ancestral history of psychoanalysis. This moment brings together the history of Black Consciousness, the plight of Joseph who is sold into Egyptian slavery as a young Jewish man, who was when retrieved from prison on the recommendation of Potiphar, interprets Pharaoh's dreams and brings dream interpretation into the realm of politics:

8 'On Aug. 8, 2012, in a public lecture, Dr Mostafa Hefny, an Egyptian immigrant who lives in Detroit indicated that he wanted the U.S. government to classify him as black, not white. The Egypt-born Hefny, 61, says he's easily identifiable as a black man, but when he was admitted to the U.S. decades ago, he was classified on government papers as a White person. Hefny says he's a Nubian, an ancient group of Egyptians considered more African than Arab. According to a government directive, a White person is defined as "a person having origins in any of the original peoples of Europe, North Africa or the Middle East"" (AP Photo/Detroit News, Max Ortiz) Detroit Free Press; Huffington Post. 
Egypt's people were saved, food rationing and planning were put in place, and the masses did not die from starvation. It is important to acknowledge Egypt's vastness when dream interpretation was installed as a political act, and the foresight of planning prevented hunger, famine, and possible mass death. People were fed along the Nile, and in neighbouring countries outside of what we now consider the African continent's parameters.

It is not to Freud's Vienna that my childhood and adolescent thoughts raced as I try to deal with my psychosomatic hives which appeared annually on the anniversary of our forced removal from District Six in 1973, and for which I had no words to name their annual pilgrimage, which staged themselves on my body - the home of my psyche - as it drew the blood of my being, but to Joseph the dream interpreter who I learnt about at Sunday School. I am not religious in any way; I also grew up with Muslim cousins with whom I attended madrassa and drew from these experiences of consciousness and the unconsciousness as they best describe my psychoanalytic history.

I turn to Jacques Lacan in this segment. One cannot overlook Jacques Lacan's work on desire even if one writes on South Africa. Lacan refers to enjoyment as jouissance. There are, however, many layers to jouissance, some of which I undress in the process of this paper.

Lacan designates seven versions of jouissance and it is my contention that smaak - as a word and expression that speaks to and extends beyond the English word desire - a word spoken in Kaaps with roots in 17th century Dutch, Malay and the Khoisan languages as a direct result of our history of enslavement, spoken firstly at the Cape then over time due to migration across South Africa, surpasses jouissance and extends the limited parameters of expressions of enjoyment within the French language. Despite its weight, the word jouissance leans towards enjoyment and desire is always named within its containment. Likewise, the English word 'desire' is fraught with similar limitations never quite capturing the anticipation of enjoyment nor the salivating, lip-licking, mouth gaping effect of the word smaak that the mere utterance of the word generates, in a blink of an eye. Néstor A. Braunstein in 'Desire and Jouissance in the Teachings of Lacan, when referencing jouissance notes, 'The French word is difficult to translate in English. Lacan himself was aware of this problem ...'. And I will assert, so too was Fanon: 'To speak means to be in a position to use a certain syntax, to grasp the morphology of this or that language, but it means above all to assume a culture, to support the weight of a civilisation' (Fanon [1952] 1970: 13). 
The loose translation of lus and smaak offered here are crucial at the start of the article as they inform the reader of what is lost in the English language when referring to Black bodies at the backdrop of a language rooted in the history of English civilisation. When I presented a small segment of my work on smaak as part of a larger discourse of desire within the Black South African context at the 2020 UNISA Decolonial Summer school, the mention of the word smaak had Black women in the room giggling with their entire body. It was not simply that I was talking about sex or sexuality but smaak, as all of the women who responded with smiles understood.

In this segment, I will tackle enjoyment: firstly, as jouissance: as the concept Jacques Lacan introduces briefly in seminar one and seminar two (Lacan 1991 [1953-1954], and Lacan [1954 - 1955] 1991), where his focus is rooted in the Hegelian master and slave dialectic (still applicable to South Africa today); then over a period of 20 years Lacan shifts his focus to various components of the libidinal economy, leading us to excess enjoyment. This paper's scope limits an in-depth engagement of the said concepts; readers will have a much lengthier engagement of a broad range of case studies in my forthcoming title, Black Consciousness and the Politics of the Flesh.

It is the responses that Sparrow offers, limited to two strategic selections noted in this text, where we see the full extent of her discontent, which I suggest, among others, is rooted in her envy of Black bodies. Sparrow is dismayed at how Black bodies take to the sun, sand, and sea - a site from which Black people were legally prohibited, starting from the massacre of the Khoikhoi descended Goringhaicona people after Van Riebeeck and his settlers usurped the Cape and its beaches, to which Black people then, and still today, flock to for sustenance and enjoyment. The eyes of Sparrow, in observing Black people on the beach smack so loudly of the identification of her lack that she calls pleasure to a halt on her Facebook page by debasing Black people. I bring forth the term lack here, to suggest that Sparrow identifies a loss when recognising, through the Other, the symbolic loss of a sexuality she does not possess. In Seminar II, The Ego I Freud's Theory and in the Technique of Psychoanalysis 1954 - 1955', Lacan speaks of lack for the first time, thankfully not the last: 'Desire is a relation of being to lack. This lack is the lack of being properly speaking. It isn't the lack of this or that, but lack of being whereby the being exists' Lacan [1955] 1991, 223). Whiteness, as the property of her racialised personhood, does not allow Sparrow the ability to exercise freedom over the body and its' senses the way that she sees Black 
people exhibit. It is an exhibition to the see-er; it is not an exhibition to the doer ... not to the Black bodies who express enjoyment.

Whilst examining the presence of enjoyment with connotations that Kaaps allows, one has to address the physicality of desire, the manner in which the verbal utterances match the hand gestures, bodily gesticulations, primal sounds that have lived outside of the contamination of European languages. One smaaks with your whole body; one does not smaak in the privacy of your mind. Thought and expression are paired; expression is the cornerstone of smaak.

The English language does not offer its speakers the fully nuanced, suggestive, flavourful, mouth-watering, anticipation of seduction and lovemaking mainly because the English language of desire developed through the tight-lipped dissemination of erotic prose among the upper-class poets who borrowed words from the French language to allow themselves the elevated expression of the pleasures of sexuality that they enjoyed and kept within their class affiliation off the coast of rainy England. Words such as 'debauched' and 'debauchery' were among the most pertinent that brought the act's enjoyment to the actors, who relied on the French language to fill their tongue-tied lips with a more extensive vocabulary. The upper classes had to borrow words that were not within the English language to give expression to desire that they owned but for which words were absent. The $19^{\text {th }}$ century English working classes were referred to as breeders, and they were not afforded a sexuality. Any form of sexual relations that was evident, mainly through the process of reproduction, was viewed against the backdrop of poverty, overcrowding, children with dirty faces working in the soot-ridden environment of London, where class bore the stamp of poverty and lasciviousness (from Middle French and Late Latin), a stamp of illegality. Charles Dickens, writing in the early to middle 1800s notes this with great precision (Dickens 1838), at a time when the poor were criminalised through the New Poor Law of 1834, a year after the Slavery Abolition Act of 1833.

It is as a consequence of my lived experience as a child born in District Six, the old slave quarter of the Cape, where the previously enslaved community who were enslaved by the Dutch and forcibly brought from Bengal, Malaysia and Indonesia, the region of Java in particular, and the enslaved Xhosa from the Eastern Cape, spoke, disseminated and further developed the 17 th century language to their own needs, own desires, mostly clandestinely, away from the ears of their masters - Dutch to Kaaps. Over the 
years Kaaps became infused with the lust and desire that the enslaved maintained for our flavourful food, Javanese coffee, rose water in desserts and the bathwater, and our desire for the fragrances of the flesh. I am, as a consequence of my command of both my home Kaaps vernacular, fused with Cape Malay and the formal Afrikaans language, drawn to expressions like lus and smaak, which by far have more sensual connotations than English words like enjoyment, pleasure, lust or desire. As such, whilst I strongly assert that I do not wish to overlook the scholarly contributions of Jacques Lacan in this regard: I am here cross-referencing a Lacanian type of enjoyment, which spans a larger spectrum of enjoyment as articulated by Freud since Lacan includes, pleasure, desire, surplus pleasure and orgasmic pleasure.

I shall address both Lacan's concept of jouissance and my reliance on lus and smaak in examining Sparrow's 'Post One' and her subsequent responses wherein she references dirt, sex in the bushes, enjoyment, etc.

\section{Lus en smaak, jou lekkerding}

Smaak - a word of the Kaaps language - is referred to by linguists as a colloquial term. Kaaps is spoken primarily by the people of the Cape although its meaning, along with particular nuances that pertain to sexuality and desire have been disseminated across the country not in the absence of, or detriment to, a broad range of South African languages and/or dialects, and as such the term smaak is known, if not used as part of a verbal expression, by Black people all around South Africa to suggest, as per its derivation - libidinal desire. Smaak is a word spoken with particular delight, a word that makes you as a speaker of a language that traces your history, your spirit, your desire that lingered despite the infringement of enslavement, live forever on the tongue that speaks and performs this smaak. The Afrikaans word smaak suggests taste and crave, as would be its formal English translation, and used in the latter much like it is used in English, with particular civility. Begeer, in Afrikaans is more formal and does not have the carnal voracity of smaak. In formal Afrikaans, smaak is also a term of regularity to express a taste for food. Smaak as an expression by a Kaaps speaker refers to urges, desire, libidinal anticipation, orgasmic longing. Saying the word smaak arouses your lips, your mouth, your tongue, you salivate the minute you hear the word used in relation to a lover - yours or another - and smile when you hear the word used in reference to someone expressing their desire for another. You know it, you've been 
there, you know exactly what smaak can do, and so did Penny Sparrow. Smaak is to be tasted, the knowledge of it shared, told to another, delight taken in your desire for another, and the knowledge that the word has no brim, no border, for it overflows, and thus exceeds all notions of desire as expressed in the English language. You never have to say I smaak you with [something] or [because] ... or [like] ... there is no need for similarity or comparison. There is no reason to be declared because smaak is smaak. It says everything, and it says more than everything. If you smaak someone, it is often with a sense of hunger, 'I smaak you like a piece of bread', ... bread being your primal source of nourishment that conveys the depth and the intensity of the hunger you have for that person.

Lus, also an Afrikaans word, used to describe a desire for food and a craving for a particular food, permeates from all your pores the minute you utter the word. If you're a Kaaps speaker your desire for food cannot be expressed in English as well as in Kaaps nor as intentionally as when expressed in Afrikaans. Begeerde being more directly a translation of the English word desire, speaks to your urges, but can also be used to describe cravings. In the local Kaaps vernacular, you are permitted to lick your lips, make soft murmurings, primal sounds ... mmmmm, mmmmm, low and deep, matching the object of your lus. Lus can also be lust; it is lust that is declared, not hidden. It is demonstrated; you are allowed actions, gestures, to make your lus known. Sparrow is looking for a reason why Black people can enjoy ourselves especially at a historical crime scene - the sea and its beaches - whereupon the previously enslaved were transported, where the usurpation of the land took place, and from which we were barred, prohibited, and with the same body, through the same body, which enslavement and dehumanisation took place. And yet, our bodily Blackness, still remains a source of enjoyment despite the illogical reasoning of apartheid, the cruelty of coloniality, the forbiddenness of Black flesh as pleasure, the robbing of rights, which could never effectively legislate against desire. How can this be history? Sparrow asks. How can progress of the consciousness of freedom - a rewording of the Hegelian articulation of history - come in this form where Black people disrobe from apartheid and enjoy their bodies, enjoy with such excess, and enjoy to the point of sexual pleasure with orgasmic leisure?

World history, the development of spirit in time, not only as per the articulations put forward by Hegel but as the enactment of a democracy - even if it is White women's fake orgasm - that is declared, that offers the oppressed 
the possibility of freedom on the assumption that the oppressed has earned its freedom; that suffering, in the midst of observing the master, learning the ways of the master, that it would provide the basis for imitation as human. Here, however, the master as White madam learns from the enslaved; she learns with her lack (as a bodily instrument), and of her lack (as a loss). The master learns that the enslaved does not contain, suppress, withhold, denounce or bar the very fabric of a sexual identity that was denied - that is, the many qualities of enjoyment, love, desire, pleasure, orgasmic pleasure, and surplus pleasure. We know that reason requires judgement: it is not a pure algorithm that can be set up and left to run by itself to produce true conclusions because one has to produce the content against which one is casting judgment and Sparrow cannot. Sparrow cannot produce true conclusions because she has not offered reasons for its foundation, nor the means to establish it.

Penny Sparrow and Vanessa Hartley draw from their knowledge of the enslaved-along with the knowledge of Black people and Africans to rationalise why Black people should not be on beaches. In their articulations of racism as reason, Black skin is reason enough. In Hartley's articulation the action to prevent Black skin from expanding on beaches - 'tie them up with a rope', she writes, is her action, her justification: to save Hout Bay, the bay that was never hers, the bay along with many bays that were usurped so that she could experience masterdom as enjoyment and deny it to the 'African' as referenced in her posting. It is, after all, the settler who wants what the Indigenous inhabitants have as a lifestyle; it is the settler who has to usurp, rob, steal, maim, massacre, legislate and isolate ... to have what the Indigenous has as life, living, continuity, enjoyment, sustenance. It is the envy of the settler of the enjoyment of the native that drives coloniality.

In Lacan's seminar seven (Lacan 1998), The Ethics of Psychoanalysis 1959 - 1960, we see a much more extensive elaboration of jouissance:

i. In seminar seven, Lacan discusses jouissance as inscribed within the law. I shall here bring forth South African writer Lewis Nkosi's Mating Birds, set in early 1980s apartheid South Africa, to further Lacan's articulation. In Mating Birds, the White woman has desire for the Black man whose only transgression is the apartheid law of prohibition, which does not allow him to be on the legally assigned 'Whites Only' beach. Mating Birds is apt when examining this component of jouissance and the law. Nkosi's book draws attention to a young Black man who wanders about the city 
of Durban, jobless and aimless, strolls on the beach and crosses over into the Whites-only section, where he sees a scantily clad young White woman lying on the beach and observes her body with bewilderment, only to find her playing along. Not only did Nkosi choose a topic such as the segregated beach as the plot for his first novel, the beach and its mapping of segregation with the undercurrent of forbidden desire placed under the rule of the body politic of the 1980s, the law seemed to be begging for sexual and literary transgressions. Smaak is articulated here as the desire that emerges out of transgression ignited when the Black man demands that the White woman recognises him and recognises his physical presence instead of ignoring him. 'She lay there in my path like a jibe, a monstrous provocation, and yet she was not really aware of my presence. People like her never are' (Nkosi 1987: 7). In the novel, it is the White woman who when caught in the illegal act turns to the law for she cannot admit her desire for the Black man, and calls out rape. She has to justify the law of apartheid, which is the law of forbidden desire. She denounces her desire and relies on the law of racism to punish the man she has just had consensual sex with, in order to punish him for letting her see ... see herself, with him as her lover, and experience her desire for him. It is after all his fault. If he did not show himself, she would not have broken the law or known why it was there - which I contend was designed to protect herself against herself; that it was designed to protect her against seeing the Black man and coming face-to-face with her desire for him. In the chapter titled, 'The Jouissance of Transgression' (Lacan [1986] 1992: 191ff), Lacan makes this clear. 'The resistance to the commandment, 'Thou shalt love they neighbour as thyself' and the resistance that is exercised to prevent his access to jouissance are one and the same thing' (Lacan 1992: 194). Indeed, we learn much about psychoanalysis from the architects of apartheid who would not allow White women to have Black men as neighbours!

ii. What Lacan describes as 'uninhibited jouissance which is not threatened ...'. Lacan suggests that it is the law's jouissance, in other words lus and smaak have to be put under the law, which as we know, was legislated across the colonised world as part of the containment of the native, the Black, the African, the Indigenous. The South African Immorality Act of 1927 (Act No. 5 of 1927) forbade sexual relations between White people 
and Black people and was amended by the South African Immorality Amendment Act of 1950 (Act No. 21 of 1950) that forbade sexual relations between White people and people of other races; the Population Registration Act No 30 of 1950 ensured that racialised identities were classified and registered; the Reservation of Separate Amenities Act, Act No 49 of 1953, the Group Areas Act of 1950 and the forced removals based on the latter, among others, were all attempts by the law of the land - at the time, the Apartheid regime.

iii. Lacan's second argument in seminar seven asserts that jouissance is evil. As such, 'the jouissance of the enslaved causes the master his suffering'. The master suffers because the master is not able to contain, suppress, deny, what the enslaved brings to the landscape of recognition. The master, in order to assert and convince herself of difference, conceives of the slave as the personification of lust and desire. Sparrow has given us an indication of this in every argument she articulated in her many responses. It is therefore evil because it cannot be circumscribed to any law, any God, any religion, and speaks to an animality that speaks Kaaps, that speaks Zulu, that speaks Xhosa, that speaks the language of the people and as such this language of desire cannot be translated into English, for the English coloniser. Sparrow's monkey is not just one that litters, it is an animality that shows its lus, spreads its smaak, unashamedly, everywhere, food, fornication, imagined bushes, flora, are part of Sparrow's imagination; it is forced outside of the apartheid mapping, the geographyical fake orgasm of the White woman and into the libidinal economy of the Black person who feeds and fornicates with a pleasure that haunts the settler.

iv. The second articulation is linked to the first, quite strongly, in the sense that the master suffers when there is face-to-face with the jouissance of the formerly enslaved and previously disadvantaged. I use the latter with some contempt because the colonised has been disadvantaged, cut off from, smaak as the mastery of desire. The master's suffering is the lament but also the freedom, rapidity, omnipotence, of the lus and smaak, for which the laws of the superego do not apply. Lus and smaak defy history, because it cannot be spoken or written in the language that prescribes its limitation or its prohibition. 


\section{Conclusion}

In this paper, I have drawn on Penny Sparrow's outburst on her social media page to examine how Black bodies are treated when on South African beaches during the summer months, and the cruelty of these narratives, which have come from White women, primarily. In foregrounding Sparrow's post over Hartley's, which received less coverage as her engagement was shorter on the subject matter, I unpack the vocabulary with which Sparrow engraved her discontent as a White woman who has to share the lily-white KwaZulu-Natal shore with Black people on new year's day. The unpacking of Sparrow's post raised questions about the White gaze upon the Black body when Blackness is revealed in acts of enjoyment and pleasure, not labour or servitude.

Part of doing this unpacking of Sparrow's text, and setting the broader context by referencing Hartley from Hout Bay and Catzavelos from Gauteng, is to show how narratives of cruelty become 'master narratives' - racists speeches, in written texts, shared and disseminated, directed at Black bodies by White people who still consider this outpour of disgust as their right, their 'right to ridicule'. Thus, these narratives of embodiment and disembodiment that appear on public platforms that decolonial scholars have to face, as we come to terms with the larger and perhaps more personal landscape of the decolonial project, are crucial for unpacking as they define social discourses on race and coloniality in ways that the academy does not. None of the work that we do as scholars of decoloniality can overlook embodiment or disembodiment nor can we overlook public platforms such as social media where these are expressed and reproduced.

In South Africa, with \#KingGeorgeMustFall, at UKZN, \#RhodesMustFall, which started at UCT, the students at the time asked: how can we be in a space, a supposedly post-apartheid space, with grotesque statues that drive home the point of colonial embodiment in stone, a reminder of the memory of colonisation that lasted longer than flesh or time itself? Students, the small group that I saw protesting and defacing King George V's statue, did not want to be reminded of all the things King George $\mathrm{V}$ had done in their province - indirectly to some, directly to others. Not only does South Africa have the highest population of people from India on the African continent, many of whom were brought to the KZN province as indentured labourers, King George V was the last emperor of India, and Natal (the name of this province during apartheid) was the last pillar of the British empire. The 
defacing that I speak of is one that saw King George V's face strewn with paint, mocking his presence on a now primarily Black university, where the entrance to Memorial Tower Building just a few feet away, the arch under which I walk to enter this tower of memory, still has the names of the World War II 'heroes' neatly inscribed on the marble that engraved their victory for the British empire. The embodiment of King George V and Cecil John Rhodes, now deceased, come in the form of statues: they are reminders of colonialism, conquest, subjugation and usurpation. The coloniser needs the statue to mark a victory for itself and for the colonial who stays. The coloniser wants to see, with deeply narcissistic interest, the reflection of the coloniser in the eyes of the colonised who are forced to look, to gaze, to practice the memory of defeat each time they walk by and gaze up at a statue. Statues speak to the engravement of acts of cruelty into stone with the head of the victor as the main emblem of pride for the coloniser. This preoccupation with statues made of stone is very much an act that not only seeks to memorialise colonisation but one that seeks affinity to a religious act such as Moses receiving the commandments, carved in stone, therefore making the statue as though an act of divinity compelled by God. Statues of colonisers are not only acts of embodiment but acts of memorialised fantasies, put on display, so that we the colonised are reminded, daily, of our defeat.

As scholars embroiled in the decolonial project of learning to 'undo' and learning to understand what there is to decolonise, we have to pay attention to our surrounding, to our minds and bodies, and also to what our minds and bodies have been robbed, have been forbidden to enjoy.

It is the process of understanding the layers of apartheid, the beaches and its prohibition of Black bodies that lead us to the significance of laws that barred and prevented, and the purpose they served. In doing so, we come face to face with a politics of desire, of an outpour of lack and envy that parades as disgust, because the oppression, subjugation and humiliation of the Black body still emerges, after more than 400 years of coloniality, as a body that smacks of smaak, drips with desire, and lingers with lus, long after the shackles have been removed.

Acknowledgement: Prof Rozena Maart thanks the NRF for the grant that funded some of this research work under 'Critical Times, Critical Race' project. 


\section{References}

Biko, S.B. 1978. I Write What I Like. San Francisco: Harper and Row.

Braunstein, N.A. 2003. Desire and Jouissance in the Teachings of Lacan. In Rabaté, J.M. (ed): The Cambridge Companion to Lacan. Cambridge \& New York: Cambridge University Press.

https://doi.org/10.1017/CCOL0521807441.007

Chiesa, L. 2007. Subjectivity and Otherness. A Philosophical Reading of Lacan. Seoul: Nanjang.

https://doi.org/10.7551/mitpress/7454.001.0001

Derrida, J. 1982. Margins of Philosophy. Chicago: University of Chicago Press.

Dickens, C.H. 1838. Oliver Twist. London: Hodder \& Stoughton Ltd.

https://doi.org/10.1093/oseo/instance.00121337

Fanon, F. 1970. Black Skin White Masks. London: Palladin.

Freud, S. 1966. Jokes and their Relation to the Unconscious. London: Routledge Publishers.

Hegel, G. [1807] 1967. The Phenomenology of Mind. New York: Harper Torchbooks.

Hegel, G. [1837] 1991. The Philosophy of History. New York: Prometheus Books.

Lacan, J. 1971. Le Savoir du psychanalyste. Lecture of 4 November 1971. Unpublished.

Lacan, J. 1991a. The Seminar of Jacques Lacan Book 1: Freud's Papers on Technique, 1953 - 1954. New York: W.W. Norton \& Company.

Lacan, J. 1991b. The Seminar of Jacques Lacan Book II: The Ego in Freud's Theory and in the Technique of Psychoanalysis, 1954 - 1955. New York:

W.W. Norton \& Company.

Lacan, J. [1986] 1992. The Ethics of Psychoanalysis. Seminar Seven, 19591960. Miller, J-A. (ed.). Porter, D. (trans. with notes). New York: W.W. Norton \& Company.

Lembede, A. 2015. Freedom in Our Lifetime. Cape Town: Kwela Press.

Maart, R. 2014. Philosophy Born of Massacres. Marikana, the Theatre of Cruelty: The Killing of the 'Kaffir'. Acta Academia 46,4: 1 - 28. https://journals.ufs.ac.za/index.php/aa/article/view/1470/1447

Mahida, E.M. 1993. The History of Muslims in South Africa, 1950 - 1959. In Mahida, E.M. In History of Muslims in South Africa: A Chronology. 
Durban: Arabic Study Circle.

https://scnc.ukzn.ac.za/doc/REL/islam/Ref/Mahida_EM_History_Musli ms South Africa.pdf

Nkosi, L. 1987. Mating Birds. Cape Town: Gavin \& Sales Publishers.

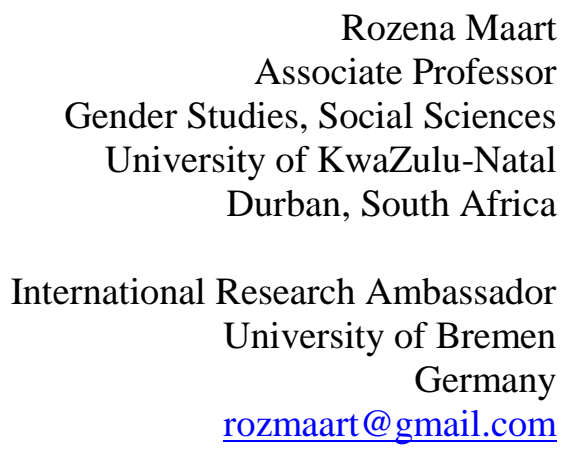

